\title{
The Booklet Development of Inorganic Fertilization System Based on Problem
}

\author{
*M. A. Yohanita Nirmalasari \& Yovita Yasintha Bolly \\ Chemistry Study Program \& Agrotechnology Program - Universitas Nusa Nipa, Maumere - Indonesia 86111 \\ Received 21 September 2020, Revised 22 October 2020, Accepted 20 November 2020 \\ doi: 10.22487/j24775185.2020.v9.i4.pp230-236
}

\begin{abstract}
The use of inorganic fertilizer in the tillage was mostly used by Sikkanese. The reason was the large supply of inorganic fertilizer on the market, fast response, easy to absorb, and not to waste times. In the implementation, inorganic fertilizer was not used accordance with the stipulation of the four rights (4T): right dose, right time, right place, and right source. The result was the decrease of soil quality and the death of soil-degrading microorganisms so that the soil became infertile. Therefore, the booklet as a learning media gave the right information about the proper fertilization system. The research aims to know the appropriateness of the booklet development of inorganic fertilization system. The method used was the research and development $(R n D)$ method by adopting a Borg and Gall model. The sample was taken by using purposive sampling. The analysis technical was validity analysis (valid percentage) and appropriate analysis (Widoyoko categorial). The result of the study showed that the booklet was appropriated to use as a medium of information for the farmer with the feasibility category both at the initial field trial and field trial stages. Furthermore, in the field trial implementation, the booklet was suitable to use with the very good feasibility category.
\end{abstract}

Keywords: The booklet, fertilization system, inorganic fertilizer, Sikka’s farmers

\section{Pendahuluan}

Kabupaten Sikka merupakan salah satu wilayah propinsi Nusa Tenggara Timur (NTT) yang memiliki penduduk dengan sebagian besar bermata pencharian sebagai petani. Kondisi ini didukung oleh potensi sumber daya pertanian lahan kering. Hasil olahan tanaman pangan pada tahun 2014 (Badan Pusat Statistik Sikka, 2020), antara lain: padi sawah $(30.39 \mathrm{Kw} / \mathrm{ha})$, jagung $(21.57$ $\mathrm{Kw} / \mathrm{ha})$, padi ladang $(23.49 \mathrm{Kw} / \mathrm{ha})$ dan ubi kayu $(93.80 \mathrm{Kw} / \mathrm{ha})$. Produksi pangan ini tidak terpisahkan dengan aplikasi pemupukan sebagai nutrisi pertumbuhan tanaman.

Pupuk merupakan bahan kimia atau organisme yang berperan dalam menyediakan unsur hara tanaman (UU No.12/1992). Ketersediaan unsur hara dapat meningkatkan produktivitas dan kesuburan tanaman pangan. Tanaman membutuhkan unsur hara dalam jumlah yang besar (unsur hara makro) dan jumlah kecil (unsur hara mikro) (Bruulsema, dkk., 2017).

Kategori unsur hara makro, diantaranya unsur nitrogen $(\mathrm{N})$, posforus $(\mathrm{P})$, kalium $(\mathrm{K})$, kalsium $(\mathrm{Ca})$, magnesium $(\mathrm{Mg})$ dan sulfur (S). Unsur hara mikro, diantaranya unsur klorin $(\mathrm{Cl})$, besi $(\mathrm{Fe})$, boron $(\mathrm{B})$, mangan $(\mathrm{Mn})$, zink $(\mathrm{Zn})$, tembaga $(\mathrm{Cu})$, molibdenum $(\mathrm{Mo})$ dan nikel $(\mathrm{Ni})$.
Unsur-unsur ini dikategorikan sebagai mineral. Adapun unsur-unsur non mineral adalah karbon $(\mathrm{C})$, hidrogen $(\mathrm{H})$ dan oksigen $(\mathrm{O})$. Berbagai unsur hara ini terkandung di dalam pupuk sesuai dengan jenisnya.

Pupuk dapat dibedakan menjadi pupuk organik yang terbuat dari bahan organik alami dan pupuk anorganik yang merupakan hasil rekayasa pabrik industri melalui proses fisika, kimia dan biologi (Dewanto, dkk., 2013). Masyarakat kelompok tani Kabupaten Sikka dalam aktivitas sehari-hari banyak menggunakan jenis pupuk anorganik untuk mengolah tanaman pangan.

Berdasarkan hasil wawancara dengan responden petani dari daerah Magepanda, Waigete dan Nebe Kabupaten Sikka diperoleh informasi bahwa tingkat penggunaan pupuk anorganik yang sangat dominan. Sebagian petani mengatakan bahwa pupuk anorganik banyak tersedia di pasaran, pengamatan respon pupuk anorganik yang cepat untuk tanaman pangan, mudah diserap dan tidak membutuhkan banyak waktu dan tenaga. Namun, petani tidak mempertimbangkan dampak yang ditimbulkan akibat penggunaan pupuk anorganik yang tidak sesuai ketentuan sistem pertanian berkelanjutan (ketentuan empat tepat atau 4T). Jika tidak tepat sumber, dosis, waktu dan tempat maka akan berakibat pada kerusakan sifat kimia, fisika dan 
biologi tanah, mematikan mikroorganisme pengurai tanah dan mengurangi tingkat kesuburan tanah. Apabila proses ini terus menerus terjadi akan merusak sistem pertanian berkelanjutan. Hal ini terjadi karena kurangnya informasi tentang sistem pemupukan kepada petani.

Pada aspek tepat sumber, petani belum memahami gejala tanaman yang kekurangan maupun kelebihan unsur hara tertentu. Pemberian pupuk yang tidak sesuai dengan kebutuhan tanaman akan mubasir bagi tanaman itu sendiri. Sebagai contoh, jika tanaman padi kekurangan unsur N, maka gejala yang ditimbulkan adalah pertumbuhan yang kerdil dan warna daun menjadi kuning (Rauf, dkk, 2010). Dengan demikian, pupuk yang sebaiknya diberikan pada tanaman padi tersebut adalah pupuk yang mengandung unsur $\mathrm{N}$, seperti pupuk NPK.

Pada aspek tepat dosis, pemberian pupuk yang tidak sesuai dengan ukuran atau takaran pada label kemasan pupuk menyebabkan tanaman dapat mengalami kekurangan ataupun kelebihan unsur hara tertentu. Pemberian dosis yang kurang mengakibatkan tanaman kerdil, sedangkan dosis berlebih akan membahayakan tanaman dan manusia dalam taraf konsumsi bahan pangan.

Pada aspek tepat waktu, petani kurang memahami dengan baik waktu pemberian pupuk, yakni sebelum tanam, saat tanam dan setelah tanam. Intensitas pemupukan selama ini tidak mengenal waktu efektivitas. Akibatnya, kandungan unsur hara tanaman pangan meningkat tidak beraturan.

Pada aspek tepat tempat, sebagian besar petani tidak mengetahui peran tepat tempat dalam pemupukan tanaman. Lokasi tanaman menentukan cara pemberian pupuk. Jika pupuk tidak tepat sasaran tempat, maka akan berhamburan dan tidak memberikan pengaruh yang baik untuk tanaman.
Berdasarkan analisis permasalahan sistem pemupukan anorganik, peneliti ingin membantu menyalurkan informasi bagi petani melalui sebuah media pembelajaran yang efektif dan kontekstual sesuai kondisi nyata petani. Buklet adalah salah satu media yang dirancang sederhana dan menarik untuk menjawab persoalan lapangan. Buklet berukuran kecil dan tipis berisi informasi yang dilengkapi dengan gambar ilustrasi, mudah dibawa dan penjelasan buklet singkat serta sistematis (Rahmatih, dkk., 2017).

Tulisan ini dimaksudkan untuk mengurai kelayakan pengembangan buklet. Beberapa penelitian pendukung, yakni: 1) pengembangan buklet penyuluhan pembuatan nata de melon yang layak digunakan sebagai media pembelajaran bagi petani buah (Nuzalifa, Utami, \& Sueb, 2019), 2) pengembangan buklet berdasarkan potensi dan kajian masalah lokal layak sebagai bahan ajar materi pemupukan (Rahmatih, dkk., 2017), 3) pengembangan media belajar buklet pembuatan nata buah sari jambu Darsono layak sebagai media pembelajaran pengrajin olahan buah (Zalita, Utami, \& Dwi, 2018).

\section{Metode}

Rancangan penelitian ini menggunakan jenis penelitian dan pengembangan (research and development) dengan mengadopsi prosedur pengembangan Borg \& Gall (Gall, dkk., 1996). Tahap penelitian ada 10 langkah, diantaranya: penelitian dan pengumpulan data, perencanaan, pengembangan draf produk, uji coba lapangan awal, revisi hasil uji coba, uji coba lapangan, penyempurnaan produk hasil uji coba lapangan, uji pelaksanaan lapangan, penyempurnaan produk akhir dan diseminasi serta implementasi. Jabaran prosedur pengembangan buklet dapat dilihat pada Gambar 1.

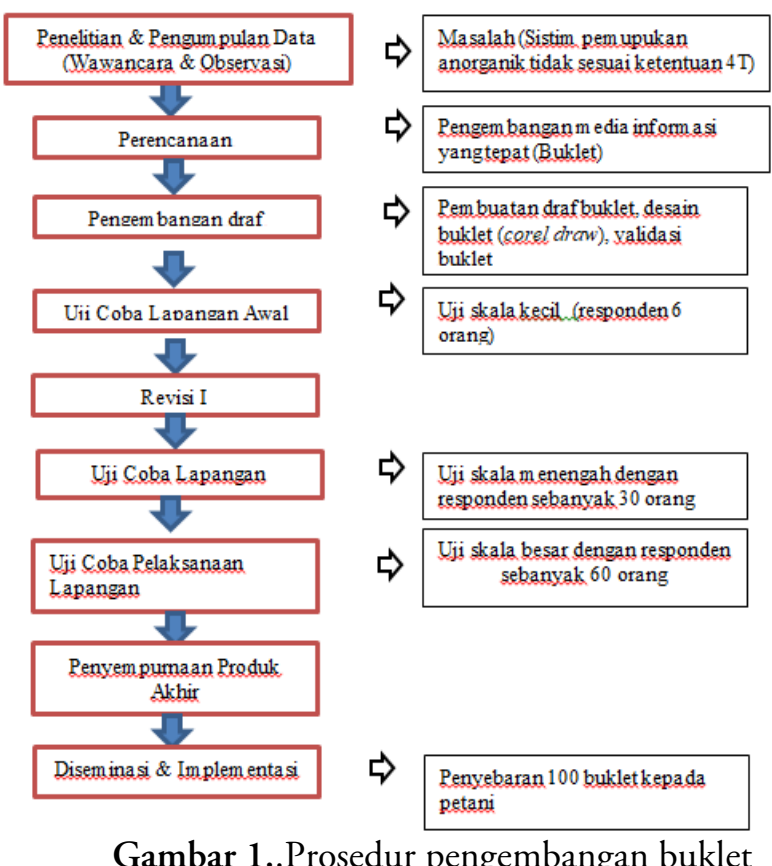




\section{Hasil dan Pembahasan}

Hasil yang diperoleh pada penelitian pengembangan ini mengikuti tahapan prosedural pengembangan buklet.

1. Penelitian dan Pengumpulan Data

Berdasarkan hasil observasi dan wawancara lapangan diperoleh permasalahan yang sangat urgen untuk menyelamatkan sistem pertanian berkelanjutan sesuai kriteria 4T di wilayah Kabupaten Sikka. Pola pemupukan anorganik yang tidak tepat sumber, waktu, tempat dan dosis menjadi permasalahan utama yang ditemukan oleh peneliti.

2. Perencanaan

Tahap ini, peneliti menganalisis permasalahan lapangan dan melakukan sharing bersama kolega serta penelusuran pustaka. Peneliti menyimpulkan perlu adanya sebuah media pembelajaran yang dapat memfasilitasi pengetahuan pemupukan anorganik bagi petani. Media yang dipilih adalah media cetak sesuai situasi dan kondisi petani. Buklet sebagai salah satunya yang dianggap sesuai dalam kemasan sederhana, praktis dan menarik untuk kalangan petani.

3. Pengembangan Draf Produk

Hasil analisis kebutuhan pada tahap sebelumnya bahwa petani tidak hanya membutuhkan pengetahuan ketentuan empat tepat pada pupuk anorganik. Peneliti mengembangkan draf utama buklet yang berisi pendahuluan, isi dan penutup. Pada bagian isi, buklet tidak membahas secara langsung pada pupuk anorganik. Peneliti merancang kerangka isi buklet yang mengenalkan petani tentang tanaman pangan, jenis pupuk hingga memfokuskan pada sistem pemupukan anorganik. Rancangan sub materi buklet, yakni:

a. Pengenalan tanaman pangan

Mencakup: defenisi, jenis dan karakterisitik tanaman pangan. Beberapa jenis tanaman pangan disesuaikan dengan banyaknya produktivitas tanaman pangan yang dihasilkan oleh petani, seperti: padi, jagung, ubi kayu, ubi jalar dan kacang tanah.

b. Pupuk dan sistem pemupukan

Mencakup: pengetahuan pupuk, jenis pupuk di pasaran, defenisi dan karakteristik pupuk anorganik, kekurangan dan kelebihan pupuk anorganik, gejala kekurangan dan kelebihan unsur hara, metode pemberian pupuk anorganik, sistem pemupukan anorganik menuju pertanian berkelanjutan.

c. Kajian penelitian tentang sistem pemupukan anorganik

Penulis menambahkan beberapa rujukan hasil penelitian tentang sistem pemupukan anorganik. Tujuannya untuk memberikan tambahan pengetahuan ilmiah bagi petani.

Rancangan draf buklet kemudian didesain menggunakan aplikasi Corel Draw. Hasilnya diteruskan pada tahap validasi materi, bahasa, media oleh masing-masing validator dan juga tiga orang praktisi mewakili petani. Data hasil validasi diperoleh dari penyebaran angket dengan menggunakan skala 4. Hasil validasi dianalisis secara kualitatif dan kuantitatif. Analisis kualitatif berupa komentar dan saran perbaikan buklet dapat diamati pada Tabel 1.

Tabel 1. Analisis kualitatif validitas buklet

\begin{tabular}{|c|c|}
\hline Validator & Keterangan Validasi \\
\hline Materi & $\begin{array}{l}\text { - Menambahkan kajian penelitian lokal yang relevan untuk daerah } \\
\text { lahan kering NTT } \\
\text { - Menampilkan gejala kekurangan dan kelebihan unsur hara } \\
\text { makro dan mikro dengan jelas } \\
\text { - Menampilkan gambar pupuk padat maupun cair }\end{array}$ \\
\hline Bahasa & $\begin{array}{l}\text { - Perbaikan layout dengan meringkas paragraf yang panjang } \\
\text { - Memuat informasi pada buklet berdasarkan poin-poin penting } \\
\text { - Pemilihan gambar terlalu kecil dan kurang jelas }\end{array}$ \\
\hline Media & $\begin{array}{l}\text { - Jenis huruf pada beberapa bagian buklet kurang jelas } \\
\text { - Pertimbangkan ukuran gambar dengan ukuran buklet } \\
\text { - } \quad \text { Melengkapi setiap contoh dengan gambar yang jelas } \\
\text { - Penjelasan tambahan pada beberapa gambar penting }\end{array}$ \\
\hline Praktisi & $\begin{array}{l}\text { - Perhatikan ukuran dan resolusi gambar } \\
\text { - Gunakan kertas jenis glossy } \\
\text { - Ukuran huruf pada tabel terlalu kecil } \\
\text { - Ukuran buklet diperbesar } \\
\text { - Koreksi pernyataan kontradiktif pada halaman } 8 \text { buklet tentang } \\
\quad \text { akivitas pertanian }\end{array}$ \\
\hline
\end{tabular}

Selain analisis kualitatif, validasi buklet dapat ditinjau secara kuantitatif dengan menghitung persentase kevalidan sesuai rumus berikut (Arikunto, 2010):

Persentase $=\frac{\Sigma \text { skor total }}{\Sigma \text { skor maximal }} \times 100 \%$ 
Tabel 2. Kriteria validitas buklet

\begin{tabular}{cc}
\hline Kriteria (\%) & Kategori \\
\hline $85,01-100,00$ & Sangat Valid \\
$70,01-85,00$ & Valid \\
$50,01-70,00$ & Cukup Valid \\
$01,00-50,00$ & Tidak Valid \\
\hline
\end{tabular}

Kategorial nilai kevalidan disesuaikan dengan pendapat Akbar (Hera, dkk., 2014) pada

Tabel 2. Berdasarkan perhitungan sesuai

persamaan (1) dan hasil tabulasi sesuai Tabel 2, diperoleh persentase validitas buklet yang dapat dilihat pada Tabel 3 .

Tabel 3. Persentase kevalidan buklet

\begin{tabular}{lcl}
\hline \multicolumn{1}{c}{ Validasi } & Persentase & \multicolumn{1}{c}{ Kategori } \\
\hline Materi & 84,72 & Valid \\
Bahasa & 82,50 & Valid \\
Media & 77,78 & Valid \\
Praktisi I & 74,19 & Valid \\
Praktisi II & 91,13 & Sangat Valid \\
Praktisi III & 90,32 & Sangat Valid \\
Rerata Kevalidan & 83,44 & Valid \\
\hline
\end{tabular}

Selanjutnya, data pada Tabel 3 dapat disederhanakan seperti yang terlihat pada Gambar 2.

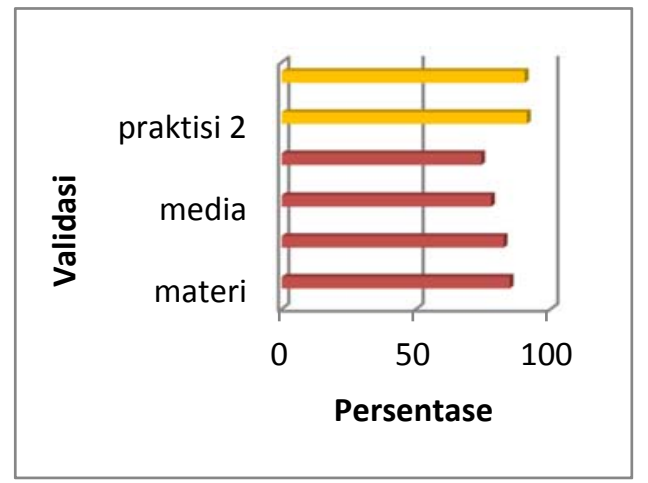

Gambar 2. Hasil validasi buklet

Gambar 2 menjelaskan bahwa rerata persentase validitas buklet berada diatas 50\% yang merupakan batas kategori cukup valid. Artinya, buklet sistem pemupukan anorganik memenuhi kategori valid bahkan sangat valid. Buklet telah melalui proses uji kevalidan secara materi, penggunaan bahasa, media dan sisi kepraktisan penggunaan secara langsung oleh responden pengguna. Persentase tertinggi yang mewakili kategori sangat valid oleh dua orang praktisi lapangan (praktisi 2 dan praktisi 3). Kendala yang dihadapi oleh perwakilan praktisi pada tahap validasi adalah ukuran huruf dan ukuran buklet. Peneliti menerima masukan ini dan mempertimbangkan sisi keterbacaan buklet. Pertimbangannya adalah sebagian petani memiliki rerata usia lanjut, sehingga banyak kendala pada indera penglihatan.

4. Uji Coba Lapangan Awal

Buklet hasil validasi direvisi oleh peneliti dan dilanjutkan dengan uji coba kelayakan. Instrumen penilaian kelayakan mengacu pada skala 4 menggunakan kuisioner. Isi kuisioner disesuaikan dengan kebutuhan keterbacaan buklet, meliputi aspek konten dan penyajian materi, kesesuaian bahasa, desain grafis dan kepraktisan buklet. Hasil uji coba pada skala lapangan awal diperoleh hasil dengan rerata skor kelayakan sebesar 132,20. Perhitungan ini mengacu pada kriteria kategorial Widoyoko (2013) dimana tabulasi perhitungannya dapat dilihat pada Tabel 4. 
Tabel 4. Kriteria kelayakan buklet

\begin{aligned} & \hline Rentang Skor \multicolumn{1}{c}{ Kategori } \\ & \hline$X>146,20$ Sangat Baik \\ & $120,40<X \leq 146,20$ Baik \\ & $94,60<X \leq 120,40$ Cukup Baik \\ & $68,80<X \leq 94,60$ Kurang Baik \\ &$X \leq 68,80$ Sangat Kurang Baik \\ & \hline\end{aligned}

Hasil yang diperoleh pada tahap uji coba lapangan awal menyatakan bahwa buklet layak digunakan oleh petani dengan kategori kelayakan yang baik. Meskipun hasil uji kelayakan baik, buklet masih harus direvisi sesuai saran responden.

\section{Revisi Hasil Uji Coba}

Revisi pada tahap ini oleh 6 orang petani pada uji coba lapangan awal hanya mencakup ketidakjelasan jenis huruf, ukuran huruf dan ukuran buklet, sehingga sangat mempengaruhi keterbacaannya. Buklet kemudian direvisi dan dilanjutkan pada tahap uji coba lapangan.

\section{Uji Coba Lapangan}

Perhitungan kelayakan buklet pada tahap uji coba lapangan diperoleh hasil rerata skor sebesar 132,00. Dasar perhitungan yang sama sesuai Tabel 4. Hasil yang diperoleh menyatakan bahwa buklet layak dengan kategori baik.

7. Penyempurnaan Produk Hasil Uji Coba Lapangan

Pada bagian ini, petani lebih banyak memberikan masukan untuk pengembangan buklet. Revisi pada bagian ini dapat dilihat pada Tabel 5 .

Tabel 5. Revisi tahap uji coba lapangan

\begin{tabular}{|c|c|}
\hline \multicolumn{2}{|c|}{ Revisi } \\
\hline Sebelum & Sesudah \\
\hline Sampul depan buklet berwarna orange & Sampul depan buklet berwarna hijau \\
\hline $\begin{array}{l}\text { Profil petani menggunakan pakaian } \\
\text { sarung tenun sikka (mengangkat budaya } \\
\text { sikka, namun tidak sesuai konteks buklet) }\end{array}$ & $\begin{array}{l}\text { Profil petani sudah menggunakan } \\
\text { atribut petani yang melakukan aktivitas } \\
\text { sedang memberikan pupuk anorganik } \\
\text { pada salah satu tanaman pangan (padi) }\end{array}$ \\
\hline Jenis kertas sampul kurang tebal & Kertas sampul lebih tebal dengan \\
\hline Beberapa gambar dengan resolusi rendah & laminasi cover \\
\hline $\begin{array}{l}\text { Belum mencantumkan nama pupuk daun } \\
\text { dan akar }\end{array}$ & $\begin{array}{l}\text { Perbaikan gambar dengan resolusi lebih } \\
\text { baik }\end{array}$ \\
\hline Penjelasan ketentuan 4T kurang lengkap & $\begin{array}{l}\text { Sudah mencantumkan nama pupuk } \\
\text { daun dan akar }\end{array}$ \\
\hline & $\begin{array}{l}\text { Tambahan penjelasan } 4 \mathrm{~T} \text { bagian tepat } \\
\text { jenis }\end{array}$ \\
\hline
\end{tabular}

8. Uji Pelaksanaan Lapangan

Dengan adanya perbaikan pada uji coba lapangan, buklet di uji kelayakannya dengan responden yang lebih luas, yakni 60 responden. Perhitungan rerata skor dan disesuaikan dengan kategori kelayakan pada Tabel 4 maka diperoleh angka sebesar 146,57. Dengan demikian, buklet pada uji pelaksanaan lapangan sangat baik atau sangat layak digunakan sebagai media informasi pengetahuan bagi petani.

\section{Penyempurnaan Produk Akhir}

Buklet hasil uji tahap akhir akan disempurnakan menjadi produk akhir penelitian pengembangan. Adapun saran salah satu responden uji kelayakan buklet bahwa komentar positif yang baik untuk keberadaan buklet pada kuisioner dapat ditambahkan pada sampul belakang buklet. Hal ini bertujuan untuk meningkatkan promosi buklet pada kalangan petani secara khusus dan masyarakat pada umumnya. Hal lainnya bahwa data kualitatif ini dapat dimasukkan pada buklet, sehingga nampak adanya proses pengembangan buklet melalui uji kelayakan. Selanjutnya, buklet siap dicetak dan difasilitasi hingga mendapat nomor ISBN.

10. Diseminasi dan Implementasi

Tahap ini, peneliti menyebarkan 100 buah buklet produk akhir kepada petani. Peneliti terus berkoordinasi dengan pihak kelompok tani untuk memantau proses pemupukan anorganik dengan adanya kehadiran buklet.

Perkembangan hasil uji coba buklet pada ketiga tahap uji coba dapat dilihat pada Gambar 3. 


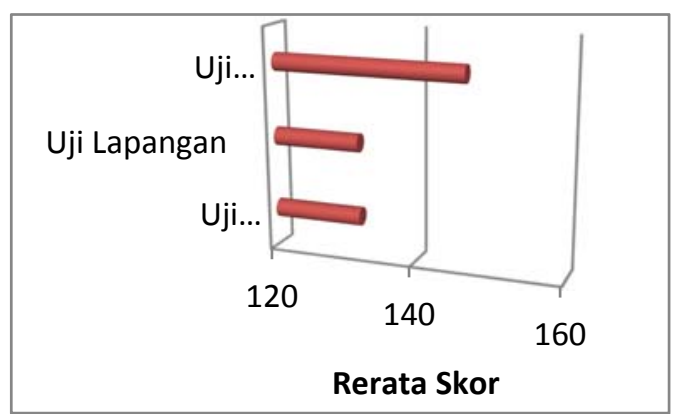

Gambar 3. Hasil uji kelayakan

Hasil uji kelayakan buklet pada Gambar 3 menunjukkan bahwa tidak ada perubahan yang signifikan pada uji tahap lapangan awal dan uji lapangan. Kisaran rerata skor berada konstan pada kriteria kelayakan baik. Namun, perubahan terjadi secara signifikan terlihat pada pelaksanaan uji coba tahap akhir (uji pelaksanaan lapangan). Pada tahap ini, rerata skor kelayakan mencapai 146,57 dimana termasuk dalam kategori kelayakan sangat baik.

Berdasarkan data uji coba kelayakan, peneliti dapat menganalisis beberapa poin, antara lain: 1) adanya penyesuaian dan pengenalan buklet sebagai salah satu media yang masih asing bagi petani Sikka terutama pada uji coba lapangan awal dan uji lapangan., 2) penyesuaian yang dimaksud pada poin 1 mulai teratasi dimana petani lebih mengenal bentuk buklet, kajian isi dan manfaatnya. Dengan demikian, perbaikan lebih sistematis dan terperinci sesuai kebutuhan petani pada uji tahap akhir. Beberapa poin yang menjadi kekurangan pada uji coba sebelumnya telah dilengkapi, sehingga turut mempengaruhi peningkatan rating scale dalam pengisian kuisioner kelayakan.

Pengembangan buklet didasarkan pada adanya masalah yang terjadi di lapangan. Masalah yang dimaksud adalah ketidaktepatan penggunaan pupuk anorganik sesuai dengan aturannya. Petani membutuhkan informasi berupa pengetahuan dengan berbagai konsep penyuluhan sebagai proses pembelajaran. Kelemahan metode ini adalah daya ingat yang terbatas dengan teknik penyampaian secara lisan. Oleh karena itu, peneliti memberikan solusi dengan mengembangkan buklet sederhana sebagai media cetak untuk membantu petani. Kegiatan penyuluhan akan menjadi efektif apabila didukung oleh media berupa bahan ajar (buklet).

Pralisaputri, dkk. (2016) mengungkapkan bahwa kelebihan buklet yang bersifat informatif dengan desain menarik akan menimbulkan rasa ingin tahu, sehingga berdampak pada pemahaman yang lebih mudah. Efek ini dapat diamati pada uji coba tahap akhir dimana petani lebih mudah mengingat ketentuan sistem pemupukan anorganik. Pengetahuan ini tidak hanya berada dalam ingatan sepintas, melainkan bertahan lebih lama. Bahkan, pada tahap diseminasi, peneliti akan menyerahkan buklet produk akhir untuk menjadi milik petani secara individu. Buklet sebagai salah satu media yang berisi pengetahuan yang dikemas secara sederhana. Eschalier, dkk. (2013) mengemukakan bahwa buklet sangat efektif dalam meningkatkan pengetahuan.

Dalam penelitian ini, buklet sistem pemupukan anorganik telah melewati uji validasi dan kelayakan dan diperoleh hasil valid dan layak digunakan oleh petani. Buklet sistem pemupukan ini dirancang sedemikian rupa sehingga berisi pengetahuan singkat, padat dan jelas serta praktis.

Hasil penelitian yang sama dikembangkan oleh Edy, dkk. (2017) dalam pengembangan booklet penyuluhan nata de matoa bagi petani. Hasilnya valid dan layak karena karakteristik buklet yang dikembangkan tidak jauh berbeda dengan buklet sistem pemupukan anorganik, yakni memiliki nilai positif pada sisi kemenarikan dan keterbacaan buklet. Hasil serupa yang menjadi kelebihan buklet sistem pemupukan anorganik adalah berisi gambar untuk memudahkan pemahaman petani, huruf standar untuk petani, background dengan warna dasar hijau sesuai keadaan pertanian dan sampul depan buklet berupa profil salah satu petani daerah Sikka. Hal ini akan memotivasi petani untuk membaca, mengenal dan mempraktikan pengetahuan dan keterampilan pemupukan anorganik.

Kebutuhan buklet tidak hanya untuk kalangan petani. Dalam proses penelitian, permintaan buklet juga datang dari kalangan penyuluh pertanian. Buklet secara tidak langsung sangat berperan dalam proses pendidikan non formal, yakni pendidikan keterampilan dan pelatihan kerja (Wijayanti, dkk., 2016). Lebih lanjut, Jumani, dkk. (2011) mengutarakan bahwa pendidikan non formal berperan dalam meningkatkan pengetahuan dan keterampilan untuk meningkatkan taraf hidup dengan memanfaatkan potensi sumber daya alam dan sumber daya manusia. Pendapat ini mendukung adanya buklet dalam memberikan proses pembelajaran berupa pengetahuan dan keterampilan dengan mengkaji kekayaan sumber daya alam daerah Sikka dengan ketersedian lahan pertanian tanaman pangan dan sumber daya manusia, yakni masyarakat petani.

\section{Kesimpulan}

Berdasarkan prosedur pengembangan buklet dan hasil analisis data dapat disimpulkan 
bahwa buklet memenuhi kriteria valid. Uji kelayakan menunjukkan hasil buklet layak digunakan oleh petani sebagai media informasi pengetahuan. Pada uji coba lapangan awal dan uji coba lapangan buklet layak digunakan dengan kategori baik, sedangkan pada uji pelaksanaan lapangan, buklet layak digunakan dengan kategori kelayakan sangat baik.

\section{Ucapan Terima Kasih}

Penulis mengucapkan limpah terima kasih kepada pihak kemenristekdikti atas bantuan fasilitasi dana penelitian dosen pemula. Selain itu, ucapan terima kasih kepada pihak penerbit media sains Indonesia yang membantu pengurusan penerbitan dan ISBN buklet. Spesial terima kasih untuk pengurus dan anggota kelompok tani yang telah membantu pelaksanaan penelitian.

\section{Referensi}

Arikunto, S. (2010). Manajemen penelitian. Jakarta: Rineka cipta.

Badan Pusat Statistik Kabupaten Sikka. (2020). Tanaman pangan. Diakses 14 Juli 2020, dari https://sikkakab.bps.go.id/subject/53/tanam anpangan.html\#subjekViewTab3.

Bruulsema, T. W., Fixen, P. E., \& Sulewski, G. D. (2017). 4T Hara tanaman: Pedoman peningkatan manajemen hara tanaman. Penang Malaysia: International Plant Nutrition Institute.

Dewanto, F. G., Jola, J. M. R. L., Ronny, A. V. T., \& Wilhelmina, B. K. (2013). Pengaruh pemupukan anorganik dan organik terhadap produksi tanaman jagung sebagai sumber pakan. Jurnal Zootek, 32(5), 1-8.

Edy, M. A., Utami, S. H., \& Abdul, G. (2017). Pengembangan booklet penyuluhan nata de matoa bagi para petani buah matoa. Jurnal Pendidikan: Teori, Penelitian dan Pengembangan, 2(7), 971-973.

Eschalier, B., Descamps, S., Boisgard, S., Pereira, B., Lefevre-Colau, M. M., Claus, D., \& Coudeyre, E. (2013). Validation of an education booklet targeted to patients candidate for total knee arthroplasty. Orthopedics and Traumatology: Surgery and Research, 99(3), 313-319.
Gall, M. D., Borg, W. R. \& Gall, J. P. (1996). Educational research: An introduction, 6th Edition. Boston, MA: Pearson.

Hera, R., Khailril, \& Hasanuddin. (2014). Pengembangan handout pembelajaran embriologi berbasis kontekstual pada perkuliahan perkembangan hewan untuk meningkatkan pemahaman konsep mahasiswa di universitas muhammadiyah badan aceh. Jurnal Bio Tropika, 2(2), $187-$ 250 .

Jumani, Fasal, U. R., \& Khadija, B. (2011). Potential of non formal basic education in promoting women education in Pakistan. International Journal of Instruction, 4(10), 1732.

Nuzalifa, Y. U., Utami, S. H., \& Sueb. 2019. Pengembangan media pembelajaran booklet penyuluhan tentang pembuatan nata de melon bagi masyarakat petani. Jurnal Pendidikan. 4(3), 317-321.

Pralisaputri, K. R., Heribertus, S., \& Chatarina, M. (2016). Pengembangan media booklet berbasis SETS pada materi pokok mitigasi dan adaptasi bencana alam untuk kelas X SMA. Jurnal Geo Eco, 2(2), 147-154.

Rahmatih, A. N., Ari, Y., \& Susanti, R. (2017). Pengembangan booklet berdasarkan kajian potensi dan masalah lokal sebagai suplemen bahan ajar SMK pertanian. Journal of Innovative Science Education, 6(2), 162-169.

Rauf A. W., Syamsuddin, T., \& Sihombing, S. R. (2000). Peranan pupuk NPK pada tanaman padi. Diakses 14 Juli 2020, dari http://203.190.37.42/agritek/ppua0160.pdf

Widoyoko, E. P. (2013). Teknik penyusunan instrumen penelitian. Yogyakarta: Pustaka Pelajar.

Wijayanti, E., Fatchur, R., \& Utami, S. H. (2016). Pengembangan booklet penyuluhan nata de pamelo bagi para petani jeruk pamelo di Magetan. Jurnal Pendidikan: Teori, Penelitian dan Pengembangan, 1(5), 874-880.

Zalita, H. R., Utami, S. H., \& Dwi, L. (2018). Pengembangan media belajar booklet pembuatan nata sari buah jambu darsono. Jurnal Pendidikan, 3(2), 184-187. 